\title{
Do the Stock Exchange Comment Letters Affect the Accuracy of Analysts' Earnings Forecasts?
}

\author{
Rongrong Chen* and Yuanhui Li
}

\author{
School of Economics and Management, Beijing Jiaotong University, Beijing 100044, China \\ *Corresponding author. Email: $19113061 @$ bjtu.edu.cn
}

\begin{abstract}
The economic consequences of stock exchange comment letters have received widespread attention, but empirical studies based on analysts' perspective are scarce. Through theoretical analysis and empirical testing, this paper finds that the accuracy of analysts' earnings forecasts of enterprises issued with comment letters is lower than that enterprises not consulted. Moreover, the more times the inquired enterprises received the comment letters in a year, the lower the accuracy of analysts' earnings forecasts will be. This paper expands the research on the economic consequences of stock exchange comment letters from the perspective of analysts, which can provide more valuable information for analysts to forecast.
\end{abstract}

Keywords: Comment letters, Accuracy, Analysts' earnings forecasts.

\section{INTRODUCTION}

Since the stock exchange implemented information disclosure reform measures in 2013, the Shanghai Stock Exchange and the Shenzhen Stock Exchange have gradually begun regulatory inquiries on listed companies. They also published comment letters on their website for the first time in December 2014, which attracted wide attention from the management, investors, creditors, auditors, analysts and other capital market participants. Previous studies have shown that comment letters play a good regulatory role for market level [1], company level and external audit[2]. Will analysts who provide important information to the capital markets [3] also be affected by the stock exchange's inquiries? The relationship between them has not been discussed in the literature.

This paper takes China's listed companies from 2015 to 2018 as a sample, and explores the impact of stock exchange comment letters on the accuracy of analysts' earnings forecasts through theoretical analysis and empirical testing. We find that the accuracy of analysts' earnings forecasts of enterprises issued with comment letters is lower than that enterprises not consulted. And the more times the inquired enterprises received the comment letters in a year, the lower the accuracy of analysts' earnings forecasts will be. This paper enriches the research on the economic consequences of stock exchange inquiry letters and the research on factors affecting the accuracy of analysts' earnings forecasts. The research helps to give full play to the role of stock exchange comment letters, improve the quality of analyst forecasts, and promote the efficient operation of capital markets.

\section{THEORETICAL ASSUMPTIONS}

Chen et al. (2018)[1] found that the receipt of the comment letters from the stock exchange by the listed companies will bring negative market reaction. This shows that the inquiry letter conveyed to the market "bad news" about the company's information disclosure problems [4]. Based on the information effect, the listed companies received comment letters from the stock exchange, indicating that the management has the intention to hide information or lack sufficient capacity in the information disclosure. The companies' information disclosure is relatively vague [5] and has defects, so its credibility decreases. Lower information quality will decrease the accuracy of analysts' earnings forecasts. Meanwhile, Zhang (2020)[6] found that the listed companies that received the comment letters would reduce accrued earnings management and implement real earnings management. Real earnings management with greater manipulation space and more covert [6], which will further decrease the accuracy of analysts' earnings forecasts. Thus, we propose our first hypothesis: 
H1: Compared with companies that have not received the comment letter from the stock exchange, analysts have lower forecast accuracy for companies that receive the comment letter from the stock exchange.

The stock exchange may conduct multiple inquiries on the same company within a year. There are two main reasons for this. One is that the listed company has once again been imprecise or non-compliant in the information disclosure, corporate activities or corporate governance. Second, after receiving the comment letter, the company did not respond or rectify in time according to the inquiry content. When a listed company is inquired by the stock exchange more often, it means that the listed company may deliberately hide more unfavorable information. This will further increase the difficulty of analysts' forecasts, thereby reducing the accuracy of forecasts. Based on the above analysis, we propose our second hypothesis:

$\mathrm{H} 2$ : The more times the inquired enterprises received the comment letters in a year, the lower the accuracy of analysts' earnings forecasts will be.

\section{RESEARCH DESIGN}

\subsection{Sample Selection and Data Sources}

Our study is based on a sample of publicly listed firms from January 1, 2015 to December 31, 2019 in China. And proceed as follows for data processing: (1) Eliminating the sample of financial listed companies. (2) Eliminating the sample of ST listed companies. (3) Eliminating the sample of listed companies with outliers and missing values. (4) All continuous variables were winsorized at the 1 st and 99th percentiles.

The final sample comprises 9760 firm-year observations from 2015 to 2019 . The data of comment letters comes from the documents of comment letters published on the websites of the Shanghai Stock Exchange and the Shenzhen Stock Exchange, and other data comes from the CSMAR database. The software used in this paper is stata.

\subsection{Definition of Main Variables}

\subsubsection{Dependent Variable}

Following Behn et al. (2008)[7], the calculation formula of the accuracy of analysts' earnings forecast $\left(A c c_{i, t}\right)$ is as follows:

$$
\operatorname{Acc}_{i, t}=-\left|\operatorname{Mean}\left(F E P S_{i, t}\right)-A E P S_{i, t}\right| /\left|A E P S_{i, t}\right|
$$

Among them, Mean $\left(F E P S_{i, t}\right)$ is the average value of all analysts' forecasts of the latest earnings per share for the same company before the deadline for the annual report. $A E P S_{i, t}$ is the company's actual earnings per share.

\subsubsection{Independent Variables}

Following Chen et al. (2018)[1], WXH means whether a letter of inquiry was received, which is 1 when the listed company receives the comment letter from the stock exchange, otherwise it is 0 . $C W X H$ means the number of enquiry letters received, which is the number of times that the listed company received the stock exchange enquiry letter in a year.

\subsubsection{Control Variables}

Following Behn et al. (2008), we also control the following factors that may affect the accuracy of analysts' forecasts: firm size (Size), return on assets $(R O A)$, leverage (Lev), big4 auditors (Big4), accruals earnings management $(D A)$, earnings volatility $(E V)$, earnings predictability $(E P)$, forecast period $(P e r)$, analysts following $(F O l)$. Specific variable definitions are shown in Table 1. This article also controls the dummy variables of the year (Year) and industry (Ind).

\subsection{Model Specifications}

To test the impact of stock exchange comment letters on the accuracy of analysts' earnings forecasts, we specified the following model:

$$
\begin{aligned}
& \text { Acc }_{i, t}=\beta_{0}+\beta_{1} \text { WXH }_{i, t}+\beta_{2-10} \sum \text { Controls }_{i, t}+\beta_{11} \text { Year }+\beta_{12} \text { Ind }+\varepsilon_{i, t} \\
& \text { Acc }_{i, t}=\beta_{0}+\beta_{1} \text { CWXH }_{i, t}+\beta_{2-10} \sum \text { Controls }_{i, t}+\beta_{11} \text { Year }+\beta_{12} \text { Ind }+\varepsilon_{i, t}
\end{aligned}
$$

Model (2) is to test whether the listed company has received the comment letter from the stock exchange on the impact of the accuracy of analysts' earnings forecasts. Model (3) is to test the impact of the number of comment letters received by listed companies in a year on the accuracy of analysts' earnings forecasts.

\section{EMPIRICAL RESULTS AND ANALYSIS}

\subsection{Descriptive Statistics}

The descriptive statistics of the main variables in this paper are shown in Table 2. According to Table 2, the average value of $A c c$ is -0.833 , the variance is 1.7353 , the maximum value is -0.0003 , and the minimum value is -11.76 , which shows that the accuracy of analysts' earnings forecast is quite different. The average value of $W X H$ is 0.2416 , indicating that about $24.16 \%$ of listed companies are questioned. The average number of comment letters $(C W X H)$ is 1.4266 , which means that in the sample being inquired, each company is inquired about 1.4 times per year, and a maximum of 5 times. 
Table 1. Variable definition

\begin{tabular}{|c|c|c|}
\hline & Variables & Definition \\
\hline Dependent variable & Acc & The accuracy of analysts' earnings forecast \\
\hline \multirow[t]{2}{*}{ Independent variable } & WXH & $\begin{array}{l}\text { A dummy variable taking the value of } 1 \text { when the listed company receives the comment letter } \\
\text { from the stock exchange, otherwise it is } 0\end{array}$ \\
\hline & $\mathrm{CWXH}$ & The number of comment letters received from the stock exchange in a year \\
\hline \multirow{9}{*}{ Control variables } & Size & Natural logarithm of total assets \\
\hline & $\mathrm{ROA}$ & Ratio of return on assets \\
\hline & Lev & Debt ratio \\
\hline & Big4 & $\begin{array}{l}\text { An indicator variable defined as } 1 \text { if the auditor of the company is a Big } 4 \text { auditor, and } 0 \\
\text { otherwise }\end{array}$ \\
\hline & DA & Accrued earnings management, calculated according to the modified Jones model \\
\hline & EV & The standard deviation of the return on equity for the first 5 years \\
\hline & EP & The absolute value of the ratio of operating profit to total profit \\
\hline & Per & $\begin{array}{l}\text { The natural logarithm of the time interval between the release date of analysts' earnings } \\
\text { forecasts and the release date of annual report, and the average value is taken when multiple } \\
\text { analysts forecast the same company in a year. }\end{array}$ \\
\hline & Fol & The number of analysts forecasting the company's earnings in a year. \\
\hline
\end{tabular}

Table 2. Descriptive statistics

\begin{tabular}{|l|l|l|l|l|l|l|}
\hline variable & N & Mean & Median & SD & Max & -0.0003 \\
\hline AcC & 9760 & -0.8330 & -0.2357 & 1.7353 & -11.7600 \\
\hline WXH & 9760 & 0.2416 & 0.0000 & 0.4281 & 1.0000 & 0.0000 \\
\hline CWXH & 2358 & 1.4266 & 1.0000 & 0.8127 & 5.0000 & 1.0000 \\
\hline Size & 9760 & 22.6345 & 22.4470 & 1.2736 & 26.4580 & 20.3213 \\
\hline ROA & 9760 & 0.0457 & 0.0415 & 0.0575 & 0.2144 & -0.1924 \\
\hline LeV & 9760 & 0.4338 & 0.4279 & 0.1950 & 0.8654 & 0.0679 \\
\hline Big4 & 9760 & 0.0657 & 0.0000 & 0.2477 & 1.0000 & 0.0000 \\
\hline DA & 9760 & 0.0718 & 0.0461 & 0.0881 & 0.6122 & 0.0011 \\
\hline EV & 9760 & 0.0564 & 0.0311 & 0.0876 & 0.6472 & 0.0026 \\
\hline EP & 9760 & 0.9639 & 0.9899 & 0.2557 & 2.5846 & 0.1739 \\
\hline Per & 9760 & 5.2874 & 5.3602 & 0.4982 & 6.0814 & 3.1355 \\
\hline Fol & 9760 & 14.4637 & 10.0000 & 13.7845 & 62.0000 & 1.0000 \\
\hline
\end{tabular}

We also conducted the correlation analysis, but the results were not reported for brevity. The correlation analysis shows that the correlation coefficients between the independent variable and control variables and VIF are relatively small indicating that the multicollinearity problem is not a concern.

\subsection{Empirical Results}

The regression results of this paper are shown in Table 3. Columns (1) and (2) show the regression results of model (2). The result in column (1) shows that the coefficient of $W X H$ without adding control variables is -0.4204 , and it is significant at the $1 \%$ level. The result in column (2) shows that control variables the coefficient of $W X H$ with adding control variables is -0.2252 , and it is significant at the $1 \%$ level. It shows that the accuracy of analysts' earnings forecasts for companies inquired by stock exchanges will be lower than that of companies that have not been inquired. The first hypothesis is verified.

Columns (3) and (4) show the regression results of model (3). The result in column (3) shows that without control variables, the coefficient of $C W X H$ is -0.2342 , and it is significant at the $1 \%$ level. The regression result in column (4) shows that the coefficient of $C W X H$ with adding control variables is -0.1481 , which is significant 
Table 3. Regression results

\begin{tabular}{|c|c|c|c|c|}
\hline \multirow{2}{*}{ Variables } & (1) & (2) & (3) & (4) \\
\hline & ferror & ferror & ferror & ferror \\
\hline \multirow{2}{*}{ WXH } & $-0.4204^{\star \star *}$ & $-0.2252^{\star \star \star}$ & & \\
\hline & $(-9.0557)$ & $(-5.1455)$ & & \\
\hline \multirow{2}{*}{$\mathrm{CWXH}$} & & & $-0.2342^{\star * \star}$ & $-0.1481^{\star \star}$ \\
\hline & & & $(-3.3165)$ & $(-2.0877)$ \\
\hline \multirow{2}{*}{ Size } & & $0.1030^{\star \star \star *}$ & & $0.1482^{\star *}$ \\
\hline & & (4.8929) & & (2.3360) \\
\hline \multirow{2}{*}{ ROA } & & $7.1320^{\star \star \star}$ & & $4.6152^{\star \star \star}$ \\
\hline & & (21.4866) & & (7.2910) \\
\hline \multirow{2}{*}{ Lev } & & -0.1326 & & -0.2531 \\
\hline & & $(-0.9916)$ & & $(-0.6840)$ \\
\hline \multirow{2}{*}{ Big4 } & & 0.0374 & & 0.0015 \\
\hline & & $(0.6905)$ & & $(0.0069)$ \\
\hline \multirow{2}{*}{ DA } & & $0.5959 * * *$ & & $0.6604^{*}$ \\
\hline & & (2.8803) & & $(1.6645)$ \\
\hline \multirow{2}{*}{ EV } & & $-1.1269^{* \star *}$ & & -0.4893 \\
\hline & & $(-3.9094)$ & & $(-1.5574)$ \\
\hline \multirow{2}{*}{ EP } & & $-0.7013^{\star * \star}$ & & $0.5351^{\star \star \star}$ \\
\hline & & $(-4.7132)$ & & (2.8413) \\
\hline \multirow{2}{*}{ Per } & & $-0.7532^{* * *}$ & & $-0.8650^{* * *}$ \\
\hline & & $(-21.2026)$ & & $(-8.9301)$ \\
\hline \multirow{2}{*}{ Fol } & & $0.0035^{\star \star \star}$ & & $0.0107^{\star \star \star \star}$ \\
\hline & & (2.9794) & & (3.1278) \\
\hline Industry & & Yes & & Yes \\
\hline Year & & Yes & & Yes \\
\hline \multirow{2}{*}{ Constant } & $-0.7315^{\star * \star}$ & $1.2141^{\star \star}$ & $-0.8686^{\star \star *}$ & 0.2419 \\
\hline & $(-39.2582)$ & (2.3519) & $(-8.3449)$ & $(0.1747)$ \\
\hline $\mathrm{N}$ & 9,760 & 9,760 & 2,358 & 2,358 \\
\hline Adj $R^{2}$ & 0.0107 & 0.1587 & 0.0061 & 0.1091 \\
\hline
\end{tabular}

Note: $\mathrm{T}$-values are reported in parentheses. ${ }^{* * *}, * *$, and $*$ denote statistical significance at $1 \%, 5 \%$, and $10 \%$, respectively.

at the $5 \%$ level. It shows that the more times the company is inquired by the stock exchange, the lower the accuracy of analysts' earnings forecasts. The second hypothesis is also verified.

\section{CONCLUSION}

Existing studies have mostly discussed the information transmission and supervision and management functions of the inquiry letter from the perspective of market and companies, but did not pay attention to the impact of stock exchange comment letters on the analysts' forecasts. Using a sample of publicly listed firms from 2015 to 2019 in China, this paper found that the accuracy of analysts' earnings forecasts of enterprises issued with comment letters is lower than that enterprises not consulted. Moreover, the more times the inquired enterprises received the comment letters in a year, the lower the accuracy of analysts' earnings forecasts will be. This paper explores the impact of stock exchange comment letters from the perspective of analysts' forecast, which is of great significance to the comprehensive study of the economic consequences of stock exchange comment letters, and improve the optimization and perfection of the securities supervision mechanism of China's capital market. 


\section{ACKNOWLEDGMENTS}

This work was supported by the Fundamental Research Funds for the Central Universities (grant number 2020YJS065), the Fundamental Research Funds for the Central Universities (grant number 2019JBWB003), Beijing Municipal Social Science Foundation (grant number 16YJB014), and the National Natural Science Foundation of China (grant numbers 71872010).

\section{REFERENCES}

[1] Y. S. Chen, Y. L. Deng, Z. Li, Does the Non-penalty Regulation Have Information Content? Evidence from Inquiry Letters, Journal of Financial Research (04) (2018) 155-171. DOI: https://doi.org/CNKI:SUN:JRYJ.0.2018-04-010

[2] W. Peng, L. M. Zhang, K. Zhong, L. F. Li, Study on the Effectiveness of Inquiry Letters:Evidence from Auditors' Behavior, Journal of Management Science 32(04) (2019) 17-30. DOI: https://doi.org/10.3969/j.issn.1672-0334.2019.04.0 02

[3] S. S. Chen, Q.Q. Liu, The Interaction and Governance Effects of External Auditors and Sell side Analysts - A literature review, Auditing Research (01) (2017) 59-68. DOI: https://doi.org/CNKI:SUN:SJYZ.0.2017-01-010
[4] P. Hribar, N. T. Jenkins, The Effect of Accounting Restatements on Earnings Revisions and the Estimated Cost of Capital, Review of Accounting Studies, 9(2) (2004) 337-356. DOI: https://doi.org/10.1023/B:RAST.0000028194.1137 1.42

[5] T. D. Fields, T. Z. Lys, L. Vincent, Empirical Research on Accounting Choice, Journal of Accounting \& Economics 31(1-3) (2001) 255-307. DOI: https://doi.org/10.1016/S0165-4101(01)00028-3

[6] Y. Zhang, Enquiry Letter Supervision and Corporate Real Earnings Management Strategy, Journal of Contemporary Finance \& Economics (03) (2020) 90-101. DOI: https://doi.org/10.13676/j.cnki.cn36-1030/f.2020.0 3.009

[7] A. Y. Zang, Evidence on the Trade-off between Real Activities Manipulation and Accrual-based Earnings Management, The Accounting Review 87(2) (2012) 675-703. DOI: https://doi.org/10.2308/accr-10196

[8] B. K. Behn, J. H. Choi, T. Kang, Audit Quality and Properties of Analyst Earnings Forecasts, The Accounting Review, 83(2) (2008) 327-349. DOI: https://doi.org/10.2308/accr.2008.83.2.3 